\title{
Authenticating History With Oral Narratives: The Example of Ekajuk Clan in Ogoja Local Government Area of Cross River State, Nigeria
}

\author{
Francis Mowang Ganyi, University of Calabar, Nigeria.
}

\begin{abstract}
It is generally accepted that oral narratives serve as a veritable means for historical reconstruction. This holds true, particularly in societies where written documents do not subsist. The Ekajuk community, though very warlike, is a relatively small community that lacks a written history. The attempt to reconstruct the history of their migrations and settlements up to present day has necessitated this write-up which is intended to serve as a reference point for future historical or anthropological work in the area. The write-up is further expected to serve as a historical record for the teaching of Ekajuk history in Primary and Secondary schools in the area.

Through interviews and oral renditions, the writer has traced Ekajuk movements and their supposed ancestors from Zululand in East Africa, through the Cameroon republic, to their present location in Nigeria. The exercise however, requires painstaking sifting of oral narratives to synthesize with oral information provided by elders in order to get a historical view-point. It is however, rewarding in the end.
\end{abstract}

\section{Introduction}

The relationship between folklore, sociology and anthropology and history has been a subject of scholastic investigation for quite sometime now and requires no further belabouring. What is perhaps worthy of note, however, is the fact that these studies have culminated in a number of assertions which explicate the place of folklore or oral narratives as undisputable sources of historical evidence that aid the reconstruction of the historical heritage of rural communities who have no written traditions. Dr. Okoi Arikpo asserts in his Lugard lecture 1957 that

\begin{abstract}
.... It is well known that societies which do not have a written literature, preserve their traditions and cultural heritage in the form of myths and folklore and the oral histories which are handed down from generation to generation in the form of legends or epics.... Most of these accounts are conjectural history, but a careful sifting of these legends and folklore may provide very valuable evidence about the people past. (Okoi Arikpo: 1957).
\end{abstract}

The history of Ekajuk clan in Ogoja Local Government Area falls largely under this category, ie conjectural history which can, as at now only be studied through careful sifting of oral narratives-folklores and legends - one of which talks about the origin 
and spread or migration of the inhabitants of the clan to their present day location.

Ekajuk (often wrongly spelt like Akaju or Akajuk) by anthropologists like C.B.C Watson (1930) and P. Amoury Talbot (1926) an Ejagham - speaking sub-group currently occupies a land area to the southern part of present day Ogoja Local Government Area of Cross River State in Nigeria occupying an area of roughly $1,300 \mathrm{~km}$. The clan lies within longitudes 80.29" East and 80.45" West and latitudes 60.20" North and 6.45 South according to R.E. Matiki (Matiki 1983).

It is bounded to the North by Nkim and Bekwarra clans, to the South by Nnam and Abaniyum clans, to the East by Kakwagom and Boki clans and to the West by Nkum and Ukelle clans respectively with an estimated population of about 56,000 (fifty six thousand) inhabitants, the clan is predominantly an agricultural area occupying a unique position between the low lands of the Cross River Basin and the high lands of Eastern Nigeria. Again Matiki Asserts that the land is marked by the absence of any striking physical features like the neighbouring Boki hills or the Obudu high lands (Matiki:1983).

P. Amoury Talbot (1926) classifies Ekajuk people as belonging to a semi Bantu stock of the Ekoi tribe. They have been further categorized by Matiki 1983 as belonging to the Bakor speaking sub-group of Ejagham found in Ogoja and Ikom Local Government Areas of Cross River State Nigeria. The larger Ejagham group however, exists in Akamkpa, Etung and the Big Qua areas of Calabar municipality. All of these groups speak varieties of the same Ejagham dialect and the variations are attributable to long periods of isolation from each other during their migrations to their present areas of abode.

Being a small part of a larger group and also due to lack of sufficient exposure, the Ekajuk clan has no detailed historical survey and thus remains unknown and unsung for a long time except to early anthropologists or Colonial administrators like C.B.C Watson (1930) and Rosemary L. Harris (1959). Occasional mention is also made of the Ekajuk clan by Percy Amoury Talbot (1926) Charles Patridge (1905), all of them anthropologists who happened to have worked in the mid Cross River basin during the Colonial era. These, however, speak of the exceptional valour or war-like disposition of the Ekajuk people which knowledge is only limited to Colonial diaries (see A. T. E Marsh 1922). The clan remains to date without any well recorded history or historical survey and it is therefore pertinent to point out here that though I am aware of this lack of a historical survey of the clan, my interest is not on the survey but to glimpse at how much of the history of Ekajuk clan can be discerned or gotten from the gamut of oral narratives in the land. My concentration in the paper is therefore to emphasize the extent to which oral narratives can aid the historian who undertakes this kind of survey.

\section{Origin of the Clan:}

The origin of Ekajuk clan, to date is still shrouded in mystery. Briefly put or according to a widely peddled oral narrative, the people of Ekajuk came from somewhere far away, probably East or central African, which view will soon be attested to later in the write-up. Their last settlement was Nsan-Araghanti in present day Cameroon republic where they still lived with their Ekagham brothers. The Ejagham language is still 
spoken in this part of Cameroon. The narrative has it that their original name was "Ndim", a name by which the people are still known by their Boki brothers. From Nsan, they moved on Northwards to settle at present day Boki hills at Agba to be specific. Their final movement took them from Agba to their present day location.

Their present name, Ekajuk was only recently given to them by their Nkum and Abaniyum neighbours all Ejagham speaking groups who were always raided by the Ekajuk people. Also according to the narrative, Ekajuk engaged in incessant intertribal wars with the Bamendas of Cameroon republic but were always defeated by the Bamendas because Ekajuk war weapons were "short spears", (the zulu type probably) which their fore-fathers had bequeathed to them. The Bamendas on the other hand had mythical bows and arrows which had the capacity to hunt and kill someone no matter where he hid. As a result Ekajuk were forced to migrate to Mombaegu from where they further migrated to Ndim-Aro. However in quest for suitable farm-land they again migrated to Eltal-Nkim somewhere around the foot of the Boki hills. Here they came in contact with the Boki people and war ensued again. The Bokis eventually enlisted the help of the Bamendas who finally drove Ekajuk people to Ekpu-Agrinya which exists today in Ekajuk and represents the last collective settlement of the Ekajuk before their dispersal to the different twelve settlements that today constitute the clan. They include Esham (the political and administrative centre), Nwang (the war leaders), Emanghendak, Etukpuk, Ndarr, and Edip. Others are Eshamkum, Ntunop, Ebanibim Ekagongho, Mfom and Nnam is in present day Ikom Local Government Area. The establishment of these settlements was justified by the need for protection of their new-found land because they served as guide posts for all inlets into Ekajuk clan.

At Ekpu-Agrinya, however, Ekajuk were still attacked several times by their Nnam Nkunu and Nkum neighbours, who though coming from the same Ejagham stock as the Ekajuk had arrived the edge of the forest earlier to occupy flat grazing ground for their animals but were now being threatened to share with the later arrivals, the Ekajuk. The narrative maintains that once on a hunting expedition, an Ekajuk hunter met a farmer from Ebanimbim, an Ekajuk flank that had earlier arrive the edge of the forest and so is today regarded as the eldest of the Ekajuk settlements. The farmer and the hunter recognized each other as brothers, re-united and formed a formidable fighting force against all other invading groups. During these wars however, they met with serious opposition from the colonial administration as at then stationed in present day Obubra. The Colonial administration sent expeditions against them which expeditions are referred to by Ekajuk people as Ebta Mojor" (literally major's war) and Ebta Egburugbrungidi (literary Brigadier's war).

The two expeditions were supposedly led by one major Gibon, later promoted to the rank of Brigadier by the Colonial offices because of his successes against native opposition.

This is essentially, an oral rendition in Ekajuk land and is steadily assuming the status of a myth or legend. An analysis of this narrative throws light on a number of historical facts or events in Ekajuk clan. First is the fact that narrative identifies farm-land as the major cause of incessant inter-tribal wars and movements engaged in by the Ekajuk. Matiki (1983) supports this view when he opines that the wars 
were as a result of increased pressure on farming land resulting from rapid population growth. Since the communities were largely agricultural communities as borne out in the narrative there was emphasis on land acquisition which resulted in inter-tribal wars. The Ekajuk fought numerous wars with their neighbours as A.T.E Marsh (1922) records. The Ekajuk were believed to be so war like that major now Brigadier Gibon insisted that they Ekajuk must break their dane guns after their defeat thus, earning the title gun breaker".

Again, the first identifiable settlement of the Ekajuk people is Nsan-Aranghanti in present day Cameroon republic which links Ekajuk with their Ejagham brothers, a sub-group of Ekoid Bantu origin with whom they share a common language and common cultural background. This group exists as earlier mentioned in Ogoja, Ikom, Etung, Akamkpa and parts of Calabar municipality as well as parts of Cameroon republic. The Ejagham people are believed to have migrated from somewhere through the Cameroon's to their present day locations. The narrative has therefore established that the people of Ekajuk and other Ejagham groups came from the same stock but parted ways probably at Nsam, the Southern flank setting at Akamkpa and Calabar while Ekajuk moved Northwards through Boki to their present abode.

Furthermore, the narrative not only explains but also justifies the locations of all present day Ekajuk settlements as a strategy for defence and effective protection against external aggression. These settlements Kris Mokum Monang (1984) describes as being reminiscent of the "Israeli type Kibautzm"... characterized by a strong sense of group identity unity and co-operation. It also explains the close affinity that exists between Ekajuk people and other Bakor groups in Ikom Local Government Area namely Nnam, Abaniyum, Nta Nselle and Nde all who consider themselves as brothers from the same Ejagham stock. Their affinity resulted in the establishment of the Bakor autural union through the instrumentality of late Philips Elgam Nakuku, the then Ntul-a-tul of Ekajuk clan between 1956-1967 and senator of the first republic.

It has already been observed that the Ekajuk were a very war like group and as A.T.E Marsh (1922) observes:

"Before the advent of Government the people of Ekajuk were constantly warring with their neighbours-Nkum, Ijillaga (Ukelle) Boki, Yalla, and even among themselves. At that time they lived in large settlements or groups of villages situated close together for mutual protection".

It is precisely this war-like disposition and the mention of short spears as Ekajuk weapons in the narrative which seems to link the Ekajuk with the Zulus. This is very significant especially when one notes that the Ekoi of whom the Ekajuk are a subgroup are a semi-Bantu group which fact could be used to buttress the assumption that the Ekajuk may infact have migrated somewhere around East or central Africa. The narrator however does not go as far as that but simple states that the short spears came from their ancestors who came from far away to live around Bamenda region but could not stay because of Bamenda hostility.

More important, however is the relationship between the Tivs of Benue State and 
the Ekajuk people of Cross River State which the narrator hints at in the narrative. The potency of the arrows mentioned in the narrative is attested to by Charles Patridge except that Patridge attributes them to the Tivs of Benue region instead of the Bamendas of Cameroon republic. Patridge says of the arrows. "Their poison is said to be the most effective known in Africa death ensuing within a few minutes after the arrow has pierced the skin. (Patridge 1905)".

However, Patridge calls the Tivs "Munchis" a name by which the Tivs were referred to by the Hausas or Fulani cattle nears or "Mitshis" by which the Ekajuk know the Tivs. Apparently Mitshis is an adulterated form of "munchis". Today the Tivs play a very important role in the economic lives of Ekajuk people as providers of labour for yam-mound making. It is also known that the same Tivs have had close contact with the Cameroonians, possibly the people of Bamenda, just beyond the Obudu Cattle Ranch which is not particularly far from Ogoja Local Government Area where Ekajuk people are found. Though the narrator does not specifically mention any connection between the Tivs and the Bamendas, it stands to reason that the Tivs may have helped the Bamendas during their wars with Ekajuk at Nsan and later came to establish closer links with Ekajuk. This is logical when one notes the fact that the Tivs have never fought wars with the Ekajuk neither do the two groups have any direct contact with one another in terms of territorial boundaries. Ekajuk people need to pass through either Bekwarra, Obudu or Yalla to get to Tiv-land. The Tivs on the other hand could easily have learnt from their Bamenda friends that the Ekajuk were agriculturists or farmers which resulted in their later friendship with Ekajuk.

Again it is significant to note that the narrative contains historical events that took place in Ekajuk in the not too distant past. It specifically explain the incursions of the British Colonial administration into Ekajuk land through war expeditions against the people led by one major Gibon which we have already mentioned. These expeditions were sent because Ekajuk people would not readily submit to Colonial control. It is believed that the first of these expeditions was about 1901 while the last one that drastically weakened and eventually destroyed the fighting capability of the Ekajuk and brought them under effective was in 1912. The same oral tradition has it that people of Ekajuk recorded a victory over the Colonial regiment through the instrumentality of one Modi-Egim who supplied the gun powder for the Canons and Dane guns used by the Ekajuk. Today, the full appellation for Ekajuk is "Ekajuk Modi-Egim", translated to mean Modi-Egim's Ekajuk because he saved them from Total annihilation by the Colonial regiment under major Gibon. To this extent the narrative could be viewed not only as a document that articulates the past history of Ekajuk but also of their fairly recent history.

Another very important historical fact which is glimpsed at from narrative is the fact that the people of Ekajuk had long standing trade relations with the Efiks of lower Cross River region in Calabar and its environs. This trade was conducted through the "Aya" river which traverses Ekajuk land and empties into the Cross River at some point in Obubra Local Government Area. Ekajuk people were known to come down the Aya River to Calabar in canoes to sell farm produce and other goods.

Elaborating on these trade links the narrator claimed that on one of the war expeditions, in an attempt to justify the war, Ekajuk people told the Colonial 
government representative that they sought access to the sea but were being prevented by their Nkunnu and Abaniyum brothers with whom they always fought. At that point, the while man asked for some drinking water and was readily provided with clean spring water. He then wondered aloud that could not understand why a people would look for an access route to the sea to get dirty water when they had been generously provided with clean spring water for drinking at their door-step. What the white man succeeded to do was to jokingly play down on Ekajuk people's real intention to get to the sea which was to gain access to the trade route and thus eliminate their Nnam and Abaniyum middle-men whom the narrator claimed always pilfered Ekajuk trader's wares on the river enroute to Calabar. There are in Ekajuk today, men who distinguished themselves in this trade which required tough and brave men to traverse that length of the Cross and Aya rivers from Calabar to Ogoja by Canoe. There is also ample evidence of inter-marriages between Ekajuk men and Efik women which produced children who are still alive as influential sons of Cross River State on both sides of the so called divide.

This far, the narrative has to a large extent, tried to put in its proper perspective, the history of the movement and wars engaged in by the people of Ekajuk. It is in this parlance and in the absence of any authentic historical documentation, the best document so far on the subsequent founding of the entity which today is Ekajuk clan in its present day location.

Although the narrative offers an account of the first settlement and eventual movement of Ekajuk people from Nsan-Araghanti in the Cameroon republic, it does not say exactly where they came from to settle therein. This information, it seems, will be looked for elsewhere. Again the folktale readily comes to mind because a number of Ekajuk cultural traits are reflected in the folktales of other peoples outside Nigeria which presuppose a certain degree of contact in the past.

The Ekajuk are basically a matrilineal group where lineage or ancestry is traced from the mother side. Even though there are other Bokor groups-Nnam, Nkim, Nkum which are matrilineal but which have tended to de-emphasize this aspect of their lives, this phenomenon cannot be said to be rampant among other Ejagham groups. This is not to say that the Ejagham were never at any point in the matrilineal but that, if they were, this aspect of their culture has not been emphasized of late. Even among the Ekajuk today matrilineage does not seem to appeal to many people. Yet this aspect of Ekajuk cucltural life seems to place them with the Kaguru of East Africa who themselves are a matrilineal group. The assertion is borne out by the fact the Ekajuk also have a version of "Hyena and rabbit" folktale which Thomas Beidelman (1961) recorded among the Kaguru" and which authenticates the matrilineal system of tracing ancestry.

According to the folktale there was once very severe famine and Hyena who was rabbit's paternal uncle proposed that they kill their mothers for food. Now, while rabbit was disposed to eating the flesh of his paternal aunt the abhorred that of his maternal relations. The tale found in these two cultures, shows to what extent a mother is revered.

Other aspect of Ekajuk cultural life reflected in the Banyanga epics in Zaire republic include blessing a son or a young man with sliver spat into his palms before 
he sets out on a journey and the use of dog-bells in a hunt to identify dogs from other animals being hunted. This is to prevent killing of dogs regarded as invaluable possessions of hunters. Dogs, to some extent, are regarded as sacred animals among the Ekajuk which is also true of the Banyanga. Incessant cries of dogs in the night is interpreted to mean that they have seen some evil within the community.

One could, however, argue that the arguments are too speculative to be regarded as any proof of a relationship with East or central Africa or that they could be traced to any other culture but as earlier noted, this is purely conjectural history and remains to be proven or authenticated through intensive research. Still another aspect of Ekajuk cultural life that is reflected in a epic from elsewhere seems to point to a different origin-somewhere around the old Mail empire. This is borne out in the Ekajuk practice of honouring their chiefs with thigh of selected wild beasts like buffaloes, Tigers, Hyenas etc. killed in a hunt, which practice also obtains among the Mandingo of Mali republic (at least of old). This is reflected $n$ the epic of Sundiata by D.T Naine (also in camara Laye's version of the epic) when a hunter/seer arrives the kings court and introduces himself thus

... "I am a hunter chasing game and come from Sangaran; a fearless doe has guided me to the walls of Nianiba. By the grace of my master the great Simbon my arrows have hit her as is befitting, oh king I have come to bring your portion." $\mathrm{He}$ took a leg from his leather sack ... D.T. Niane (1979).

These similarities in culture could as well have come about through cultural contacts especially so when one considers the wave of movements from south through East and central Africa brought about by the Mfecane wars.

Be that as it may, they (the similarities) seem to bear out the claim that the Ekajuk came from far away and journeyed through wars and conflicts to their present day home in Ogoja Local Government Area of the Cross River State. What we should try to do is to trace this origin.

I realize in this venture that the arguments I put forward are by no means conclusive. I realize also that the inconclusiveness of these arguments is bound to generate deeper studies on the Ekajuk people. What I have done, therefore, is to make some insinuations that could serve as reference points for further research into Ekajuk history. This I hope will soon be taken up in "more appropriate quarters".

\section{Works Cited}

Arikpo, Okoi, Who are the Nigerians: Lugard lectures 1957 Lagos; Ministry of Information Publishers 1957 P.10

Biebuuck, Daniel,Mwindo epic II in Hero and Chief: Epic literature from the Banyanga, Berkeley and Los Angeles: University of California Press 1978 PP. 127-173.

Beidelman, Thomas, "Hyena and Rabbit: in AFRICA No_31 1961 PP. 61-74

Harris, Rosemary L, "A note on Sculptural stones in mid Cross River Area of Southern Nigeria in MAN No_59 1959 PP. 113-114

Marsh, A. T. E, "Reports on Ekajuk Sub-tribe” in National Archives Ogoja 1922

Matiki, Raymond; Unpublished BA, dissertation submitted to the University of Lagos (1983) P.9 
Momnang, Kris M; The attitudes of rural people towards self-help in community development: A case study of Ekajuk clan. Unpublished B.Sc dissertation submitted to University of Calabar (1984) PP 24-25.

Niane, D. T'Sundiata: An epic of old Mali. Essex: Longman Drumbeat (1979) P. 4

Patridge, Charles; Cross River Natives. London: Hutchinson and Co 1905 P.88

Talbot, Percy Amoury; The peoples of Southern Nigeria. London: Oxford University Press 1926 , 6

Watson, C. B. C;Burial among the Akaju of Ogoja division, Southern Nigeria in MAN No_ 30 Nov. 1930 PP. 202-203 